\title{
Assessment of entrepreneurial potential of region in real sector of economy
}

\author{
E.Wegner-Kozlova \\ Ural Federal University named after the first President of Russia B.N.Yeltsin \\ Institute of Economics at the Russian Academy of Sciences (Ural branch) \\ Yekaterinburg, Russia
}

\begin{abstract}
Entrepreneurship is a socio-economic institutional system that harmonizes private and public interests under regulations established by law. In response to modern economic, geographic and political challenges, the study of entrepreneurship has become an urgent issue due to the possible use of its feature: flexibility with regard to market changes and innovations. The efficient performance of entrepreneurship depends on combination of the following factors: climatic, geographical, cultural, historical, administrative, and technological. Thus, on the one hand, the entrepreneurial potential at the regional level is the sum of all opportunities and measures available in a specific region at a certain period of time. On the other hand, the growth of entrepreneurial potential in the regions relies on the quantitative and qualitative development of the small and medium enterprises. Therefore, the entrepreneurship and entrepreneurial potential of the region are interdependent categories that determine the existence of each other. The opportunities available in the region for the activities of small and medium businesses promote its efficiency, which in turn forms the entrepreneurial potential of the region. There is an increasing trend in the number of small and medium enterprises in the servile sector of economy in Russia nowadays, which impedes the development of the real sector. The reasons of this trend include the methodology used to assess the entrepreneurial potential in the regions. Thus, this study considers that the entrepreneurial potential should be assessed from the perspective of the possibilities of small and medium enterprises in the real sector of economy. The subject of research is the entrepreneurship as a socio-economic phenomenon and the entrepreneurial potential in the territories. The objective of work is to apply the developed grouping of statistical indicators that allow describing the subject of research at the most informative level. The methodological tools of the work rely on the application of methods of statistical and cause-effect analysis. The major result of the work is a general description of the entrepreneurship in the regional real sector of economy, which is a combination of economic efficiency and public utility of entrepreneurial activity.
\end{abstract}

Keywords- small and medium enterprises; entrepreneurial potential, real sector

\section{INTRODUCTION}

Entrepreneurship is a complex socio-economic institutional phenomenon. From a social point of view, entrepreneurship involves the relations which are guaranteed by the right of property; it determines the development of a social class with the following defining features: civil society, responsibility, and creative labour. Thus, entrepreneurship becomes a natural guarantee of stability and economic security of the society. The development of entrepreneurship ensures the social stability, which is its requirement and activity base at the same time. The interdependence and interdetermination of these parameters lead to multiplicative effects in the social and economic development. The importance of entrepreneurship is determined by an economic aspect that consists in the possibilities of using exceptional features of entrepreneurship, e.g. flexibility, efficiency, and innovations. The predicative element of this system is the satisfaction of existing requirements with the results of tangible and intangible work. The following attributive elements should be specified:

- social and historical conditions of this phenomenon on a specific territory;

- activity results, expressed in creative labour and social responsibility;

- regulating by means of legal provisions, rules, traditions, and customs which do not contradict public and national interests.

Therefore, the entrepreneurship is a socio-economic institutional system that harmonizes private and public interests under regulations established by law, and ensures stable innovation and technical development. However, the study of the experience of technologically leading economies allows defining one common feature, that is, the highly developed system of entrepreneurship in small and medium organizational forms with the focus on the development of unique non-serial technologies and mechanisms. Thus, the methodology, proposed for assessment of the entrepreneurial potential in the regions, considers an assessment of the contribution to the general economic development made by the enterprises of a small and medium business segment in the specific economic sectors.

The efficient performance of entrepreneurship depends on a combination of the following factors: climatic, geographical, cultural, historical, administrative, and technological. The development factors of entrepreneurial activity are considered by many researchers [11]. There is a general concept that dynamic and growing economies will spur higher rates of entrepreneurship because of the greater number of available opportunities [5], but the high levels of human capital and entrepreneurial skills in the labor force are considered to be necessary too [1]. The growth rate of entrepreneurship also depends on other resources, such as angel investment, mentors, advisors, and public investment in innovation 
infrastructure [6]. Some researchers link the economic success of regions with the role of an entrepreneurial culture [2], knowledge spillovers, universities and innovation [9].

Thus, on the one hand, the entrepreneurial potential at the regional level is the sum of all opportunities and measures available in a specific region at a certain period of time. On the other hand, the growth of entrepreneurial potential in the regions relies on the quantitative and qualitative development of the small and medium enterprises. Therefore, the small and medium business and the entrepreneurial potential of the region are interdependent categories that determine the existence of each other: the opportunities available in the region for the activities of small and medium enterprises (SME) promote its efficiency; which in turn forms the entrepreneurial potential of the region.

The development of the small and medium business in Sverdlovsk region is based on the Management by Objectives. The practical implications of a complex representative assessment of the entrepreneurial potential in the region are the possibility of its use by the regional and sectoral authorities and business entities to reduce uncertainty, manage risks and to develop adequate management decisions.

The actual procedure of assessing the entrepreneurial potential involves the use of indicators that define the efficiency of regional support programs for the SME (Table 1) [12-17].

TABLE I. INDICATORS OF THE EFFICIENCY OF REGIONAL SUPPORT PROGRAMS FOR THE SMALL AND MEDIUM ENTERPRISES IN THE URAL FEDERAL DISTRICT

\begin{tabular}{|c|c|c|c|c|c|c|}
\hline Indicator/Region & 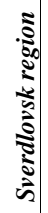 & 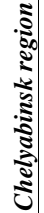 & 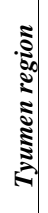 & 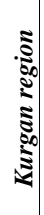 & 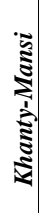 & 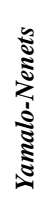 \\
\hline $\begin{array}{l}\text { Number of new jobs (including new } \\
\text { registered individual entrepreneurs) in the } \\
\text { small and medium business }\end{array}$ & + & & + & & + & + \\
\hline $\begin{array}{l}\text { Increase in the number of small and medium } \\
\text { enterprises operating on the territory of the } \\
\text { region }\end{array}$ & + & & + & + & + & + \\
\hline $\begin{array}{l}\text { Increase in the turnover of products and } \\
\text { services produced by small enterprises, } \\
\text { including microenterprises and individual } \\
\text { entrepreneurs in the region }\end{array}$ & + & & + & + & + & + \\
\hline $\begin{array}{l}\text { Number of new jobs in the small and } \\
\text { medium enterprises that received the state } \\
\text { support }\end{array}$ & + & + & + & & & \\
\hline $\begin{array}{l}\text { Number of subsidies provided to the local } \\
\text { budgets for the small and medium } \\
\text { enterprises promotion }\end{array}$ & & + & & & & \\
\hline $\begin{array}{l}\text { Number of subsidies provided to the small } \\
\text { and medium enterprises for reimbursement } \\
\text { of costs for the implementation of } \\
\text { entrepreneurial projects }\end{array}$ & & + & & & & \\
\hline $\begin{array}{l}\text { Number of loan agreements (leasing } \\
\text { agreements, bank guarantee agreements), } \\
\text { concluded by the small enterprises }\end{array}$ & & + & & & & \\
\hline
\end{tabular}

\begin{tabular}{|c|c|c|c|c|c|c|}
\hline Indicator/Region & 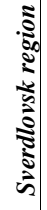 & 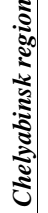 & 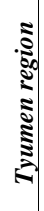 & 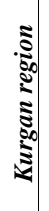 & 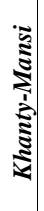 & 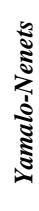 \\
\hline $\begin{array}{l}\text { Business community's assessment of the } \\
\text { implementation of support program for the } \\
\text { small and medium enterprises }\end{array}$ & + & & & & & \\
\hline $\begin{array}{l}\text { Number of the small and medium enterprises } \\
\text { that received the state support }\end{array}$ & + & & & + & & \\
\hline $\begin{array}{l}\text { Increase in the investment volume in the } \\
\text { fixed capital of the small and medium } \\
\text { enterprises in the region }\end{array}$ & & & & + & & + \\
\hline $\begin{array}{l}\text { Increase in the volume of tax revenues in the } \\
\text { consolidated regional budget from the small } \\
\text { and medium enterprises }\end{array}$ & & & & + & & + \\
\hline $\begin{array}{l}\text { Share of the average number of workers of } \\
\text { the small and medium enterprises in the } \\
\text { average number of workers of all enterprises } \\
\text { and organizations }\end{array}$ & & & & + & & + \\
\hline $\begin{array}{l}\text { Share of products produced by the small and } \\
\text { medium enterprises in the total volume of } \\
\text { gross regional product }\end{array}$ & & & & + & & + \\
\hline $\begin{array}{l}\text { Number of new registered small and medium } \\
\text { enterprises in the region }\end{array}$ & & & & + & & \\
\hline $\begin{array}{l}\text { Increase in the number of operating small } \\
\text { and medium innovativeresident companies }\end{array}$ & & & & & + & \\
\hline
\end{tabular}

The assessment of the entrepreneurial potential of the regions is also performed on the basis of the indicators that define the business support infrastructure (Table 2).

TABLE II. INFRASTRUCTURE FOR SUPPORTING SMALL AND MEDIUM ENTERPRISES IN THE URAL FEDERAL DISTRICT [3]

\begin{tabular}{|c|c|c|c|}
\hline Region & $\begin{array}{c}\text { Subjects of the infrastructure for } \\
\text { supporting small and medium } \\
\text { enterprises (units) }\end{array}$ & $\begin{array}{c}\text { Total } \\
\text { amount of } \\
\text { funds } \\
\text { (mln. } \\
\text { rubles) }\end{array}$ & $\begin{array}{l}\text { Amount of } \\
\text { funds of } \\
\text { the federal } \\
\text { budget } \\
\text { (mln. } \\
\text { rubles) }\end{array}$ \\
\hline $\begin{array}{l}\text { Kurgan } \\
\text { region }\end{array}$ & $\begin{array}{l}\text { Agency for Export Support (1) } \\
\text { Business Incubator (4) } \\
\text { Coordination Council (1) } \\
\text { Credit Assistance Fund (1) } \\
\text { Other subject of the } \\
\text { infrastructure (2) } \\
\text { Technology Park (1) } \\
\text { Chamber of Commerce and } \\
\text { Industry (1) }\end{array}$ & 139.0 & 111.2 \\
\hline $\begin{array}{l}\text { Sverdlo } \\
\text { vsk } \\
\text { region }\end{array}$ & $\begin{array}{l}\text { Centre/ Agency for Business } \\
\text { Development(1) } \\
\text { Business Incubator (3) } \\
\text { Counselling Centre (1) } \\
\text { Coordination Council (8) } \\
\text { State/ Municipal Fund for } \\
\text { Business Support (38) } \\
\text { Other subject of the } \\
\text { infrastructure (1) }\end{array}$ & 754.2 & 558.1 \\
\hline $\begin{array}{l}\text { Khanty } \\
\text {-Mansi }\end{array}$ & $\begin{array}{l}\text { Business Incubator (1) } \\
\text { Coordination Council (2) }\end{array}$ & 391.5 & 195.7 \\
\hline
\end{tabular}




\begin{tabular}{|c|c|c|c|}
\hline $\begin{array}{l}\text { Autono } \\
\text { mous } \\
\text { Region }\end{array}$ & $\begin{array}{l}\text { Financial Institution (1) } \\
\text { State/ Municipal Fund for } \\
\text { Business Support (2) } \\
\text { Other subject of the } \\
\text { infrastructure (3) } \\
\text { Technology Park (2) } \\
\text { Chamber of Commerce and } \\
\text { Industry (1) }\end{array}$ & & \\
\hline $\begin{array}{l}\text { Yamal } \\
\text { o- } \\
\text { Nenets } \\
\text { Autono } \\
\text { mous } \\
\text { Region }\end{array}$ & $\begin{array}{l}\text { Business Incubator (4) } \\
\text { State/ Municipal Fund for } \\
\text { Business Support (2) } \\
\text { Other subject of the } \\
\text { infrastructure (19) } \\
\text { Chamber of Commerce and } \\
\text { Industry (1) }\end{array}$ & 426.0 & 213.0 \\
\hline $\begin{array}{l}\text { Tyume } \\
\mathrm{n} \\
\text { region }\end{array}$ & $\begin{array}{l}\text { Other subject of the } \\
\text { infrastructure (4) }\end{array}$ & 173.0 & 138.4 \\
\hline $\begin{array}{l}\text { Chelya } \\
\text { binsk } \\
\text { region }\end{array}$ & $\begin{array}{l}\text { Business Incubator (1) } \\
\text { Coordination Council (3) }\end{array}$ & 216.2 & 108.1 \\
\hline
\end{tabular}

The use of these indicators is based on the fact that the system of state and non-state support institutions for entrepreneurs has been created at the federal level and in the majority of regions. However, it is widely recognized that the development of the SME sector faces serious obstacles and that the support policies are not very effective $[4 ; 8 ; 21]$.

The actual use of such methodology to assess the entrepreneurial potential leads to the following results. First, the share of small and medium enterprises in the total number of enterprises does not grow, remaining at a level of $40 \%$. Second, more than half $(57 \%)$ of SME turnover falls within the trade sector. Construction accounts for $11.0 \%$ of total turnover, real estate $-9.7 \%$. Together these sectors amount to approximately $80 \%$ of SME turnover [10]. This trend is typical not only for the indicators in specific regions, but at the national level. Taking into account the fact that the crisis of the financial sector had a negative impact on the indicators of the real sector [7], this is a negative trend. The increase in the number of small and medium enterprises is considered not to address a challenge of technological development of the economy, since such increase actually leads to a negative trend of growing servile sector that replaces the real sector. Thus, the entrepreneurial potential should be assessed from the perspective of the possibilities of small and medium enterprises in the real sector of economy.

\section{RESULTS}

Practical development of the regional entrepreneurship is poorly targeted at the current economic features of the regional social and economic system, as well as at the economic sectors that determine the competitive advantages of the territories. Thus, the grouping of statistical indicators was proposed in order to form the general description of the entrepreneurship in the regional real sector of economy. Such description allows illustrating a combination of economic efficiency and public utility.

To date, there are two general ways to determine the real sector of economy:
- Only as a material production.

- Considering it as the real sector of production of goods and providing non-financial non-material services on a market basis.

However, the analysis performed allows concluding that the economic "reality" (that is, the ability to satisfy natural needs and not to conflict with public interests) is not determined by the types of production (tangible or intangible), neither by the types of material production. It is determined by the social requirement for a certain economic activity to increase the national wealth [24].

The Ministry of Economics and the State Statistics Committee of Russia prepared a joint report that outlined a special section "On the Real Sector of Economy and Commodity Markets", covering industry, agriculture, communications and transportation system [20]. Therefore, the grouping of statistical indicators which qualify these areas as the real sector of economy was analyzed.

In general, the proposed methodology assumes a comprehensive assessment of the groups of indicators. These indicators qualify the industries of the real sector of economy [24].

All indicators should be considered at the two levels: "in total" and "small enterprises". However, the proposed methodology was practically applied and it revealed a number of limitations at the organizational level caused by the established practice of statistics collection.

- Obtaining and use of statistics, as the access to it is limited by the Federal Law dd. November 29, 2007, No. 282-FZ "On Formal Statistical Recording and the State Statistics System in the Russian Federation" (art. 4, item 5; art. 9, item 1).

- Different forms of statistical reports provided by: individuals engaged in entrepreneurial activities without establishing a legal entity; microenterprises; small and medium business entities; other legal entities. Differences in content do not allow comparing the results of the same economic activity performed by the different forms of enterprises.

- Different frequency of the reporting of various statistical forms.

- Groups of entities with different economic activities, that provide different forms of statistical reports.

- Lack of some demonstrative indicators in data collected by the Federal State Statistics Service.

Proposed methodology for assessing entrepreneurial potential was demonstrated in case of Sverdlovsk region.The primary data were obtained on request at the Federal State Statistics Service [23].

The assessement of industry is based on the evaluation of the following groups of production, according to the Russian Classification of Economic Activities (OKVED):

- Extraction of minerals $\mathrm{C}(\mathrm{CA}-\mathrm{CB})$ 
- Manufacturing D (DA-DN)

- Production and distribution of electrical power, gas and water E.

The following abbreviations are used in Tables 3 and 4: AN (average number of employees), NWE (number of workers per enterprise), PP (produced products), R (revenue).

TABLE III. GENERAL DESCRIPTION OF INDUSTRIAL PRODUCTION IN SVERDLOVSK REGION

\begin{tabular}{|l|l|l|l|l|l|l|l|l|}
\hline \multirow{2}{*}{$\begin{array}{c}\text { Groups of } \\
\text { production } \\
\text { according } \\
\text { to } \text { OKVED }\end{array}$} & \multicolumn{2}{|c|}{$\begin{array}{c}\text { AN (ths. } \\
\text { people })\end{array}$} & \multicolumn{2}{c|}{$\begin{array}{c}\text { NWE (ths. } \\
\text { people })\end{array}$} & \multicolumn{2}{c|}{$\begin{array}{c}\text { PP(bln. } \\
\text { rubles) }\end{array}$} & \multicolumn{2}{c|}{$\begin{array}{c}\text { R (bln. } \\
\text { rubles) }\end{array}$} \\
\cline { 2 - 9 } & 2008 & 2014 & 2008 & 2014 & 2008 & 2014 & 2008 & 2014 \\
\hline CA-CB & 36 & 29 & 0.8 & 1.1 & 55 & 56 & 56 & 56 \\
\hline DA-DN & 391 & 295 & 0.7 & 0.7 & 812 & 1218 & 864 & 1276 \\
\hline E & 67 & 62 & 0.5 & 0.4 & 98 & 180 & 109 & 287 \\
\hline
\end{tabular}

The information in Table 3 represents the decreasing average number of workers in all groups of production and the increasing number of workers per industrial enterprise in production groups $\mathrm{C}$ and $\mathrm{D}$ at the same time. This is linked with a decrease in the number of legal entities that submitted a statistical report on Form No. 1 for Enterprises, in production groups C and D in 2014 in comparison with 2008. However, the number of legal entities in group $\mathrm{E}$ increased by $33.6 \%$ in 2014.

TABLE IV. GROWTH RATE OF INDUSTRIAL PRODUCTION INDICATORS IN SVERDLOVSK REGION IN 2014 IN COMPARISON WITH 2008 (\%)

\begin{tabular}{|l|l|l|l|l|}
\hline $\begin{array}{c}\text { Groups of } \\
\text { production } \\
\text { according to } \\
\text { OKVED }\end{array}$ & $\begin{array}{c}\text { AN (ths. } \\
\text { people })\end{array}$ & $\begin{array}{c}\text { NWE (ths. } \\
\text { people) }\end{array}$ & $\begin{array}{c}\text { PP(bln. } \\
\text { rubles) }\end{array}$ & $\begin{array}{c}\text { R(bln. } \\
\text { rubles) }\end{array}$ \\
\hline CA-CB & 78.6 & 133.8 & 101.5 & 101.2 \\
\hline DA-DN & 75.4 & 103.9 & 150.0 & 147.7 \\
\hline E & 92.3 & 69.1 & 184.1 & 263.1 \\
\hline
\end{tabular}

There was an increase in the volume of produced products within the production sector in Sverdlovsk region in 2014 in comparison with 2008; the group of enterprises related to the extraction of minerals grew by $1.5 \%$, the group of manufacturing enterprises increased by $50 \%$, and the group of enterprises producing and distributing electrical power, gas and water grew by $84.1 \%$.

Revenue indicator increased over the same periods, it changed respectively to an increase in the volume of produced products in the groups $\mathrm{C}$ and $\mathrm{D}$, although the revenue growth reached $163 \%$ in the group $\mathrm{E}$.

In the group of enterprises related to the extraction of minerals, the cost structure was changed with an increase of the following other expenditures: expenditures for the purchase of goods for resale; expenditures for water; expenditures for land reclamation; stock balance of raw and other materials, purchased semi-finished products and component parts purchased for the production and sale of products (goods, works, services); stock balance of fuel for the production and sale of products (goods, works, services); insurance contributions to the Pension Fund, Social Insurance Fund, Federal Compulsory Medical Insurance Fund; employer's expenses for the payment of temporary incapacity allowance for the first three days of employee's incapacity; depreciation of fixed assets; depreciation of intangible assets; rent; mandatory and voluntary insurance payments; hospitality expenses; subsistence allowance; assignment allowance; taxes, fees and chargesincluded in the cost of production (works, services); payment under a sale agreement of forest plantations; expenditures for works and services of the third organizations; other expenditures associated with the production and sale of products.

Moreover, such type of expenditures prevails in this production group. The share of expenditures for raw and other materials decreased by $9.5 \%$ and for salaries by $1 \%$, while the share of expenditures for fuel and energy increased by $1.2 \%$ and $0.4 \%$, respectively.

The expenditures for raw and other materials prevail in the cost structure of this group. The cost structure was also shifted with an increase in the group of other expenditures by $8 \%$ in comparison with 2008. Furthermore, there was a decrease of other groups in the cost structure: salaries by $1.8 \%$, energy by $0.6 \%$, fuel by $0.6 \%$, raw and other materials by $5 \%$.

The main costs in the sector of production and distribution of electrical power, gas and water are the other expenditures. Its share decreased by $1.9 \%$ in comparison with 2008 . There was an increase of only one share of costs in this production group, it was the share of expenditures for energy with a growth about $6.4 \%$. Other expenditure groups in the cost structure reduced their share: salaries by $0.2 \%$, fuel by $1.3 \%$, raw and other materials by $2.8 \%$.

The growth rate of the different groups expenditures is indicated in Table 5. The following abbreviations are used to specify the groups of expenditures:R (raw materials), $\mathrm{F}$ (fuel), $\mathrm{E}$ (energy), S (salary), OE (other expenditures), TC (total costs).

TABLE V. GROWTH RATE OF INDUSTRIAL PRODUCTION COSTS IN SVERDLOVSK REGION IN 2014 IN COMPARISON WITH 2008 (\%)

\begin{tabular}{|l|c|c|c|c|c|c|}
\hline $\begin{array}{c}\text { Groups of } \\
\text { production } \\
\text { according to } \\
\text { OKVED }\end{array}$ & $\boldsymbol{R}$ & $\boldsymbol{F}$ & $\boldsymbol{E}$ & $\boldsymbol{S}$ & $\boldsymbol{O E}$ & $\boldsymbol{T C}$ \\
\hline CA-CB & 70 & 135 & 120 & 111 & 146 & 116 \\
\hline DA-DN & 147 & 132 & 142 & 138 & 225 & 161 \\
\hline E & 119 & 187 & 477 & 192 & 188 & 196 \\
\hline
\end{tabular}

There were only decreasing expenditures for raw and other materials in the group of productions $\mathrm{C}$ with a decline about $29.8 \%$ in 2014 in comparison with 2008. Other expenditure groups increased in all production groups. The greatest increase was shown by the energy expenditures in the sector 
of production and distribution of electrical power, gas and water. However, an increase of the expenditures for fuel and energy in all groups is accompanied by a reducing trend in the actual consumption of fuel and energy in the groups D and E, and the consumption of heat energy in the group $\mathrm{C}$ (Table 6). The following abbreviations are used in Table 6: ACEP (actual consumption of electrical power for all produced products), ACHE (actual consumption of heat energy for all produced products), ACF (actual consumption of fuel for all produced products).

TABLE VI. GROWTH RATE OF ACTUAL CONSUMPTION OF FUEL AND ENERGY IN THE SPHERE OF INDUSTRIAL PRODUCTION IN SVERDLOVSK REGION IN 2014 IN COMPARISON WITH 2008 (\%)

\begin{tabular}{|l|l|l|l|}
\hline $\begin{array}{l}\text { Groups of production } \\
\text { according to } \text { OKVED }\end{array}$ & ACEP & ACHE & ACF \\
\hline CA-CB & 132.0 & 98.0 & 121.4 \\
\hline DA-DN & 69.8 & 93.1 & 92.8 \\
\hline E & 69.6 & - & 83.2 \\
\hline
\end{tabular}

There are the following important indicators that determine the energy efficiency of economic entities: power availability per worker and energy intensity. The power availability per worker is calculated as the ratio of the amount of energy consumed to the average number of workers. This indicator represents the actual availability of energy to labor (Table7). The following abbreviations are used in Tables 7, 8, 9 and 10: EP (electrical power), HE (heat energy), F (fuel).

TABLE VII. POWER AVAILABILITY PER WORKER OF INDUSTRIAL PRODUCTION IN SVERDLOVSK REGION

\begin{tabular}{|l|c|c|c|c|c|c|}
\hline \multirow{2}{*}{$\begin{array}{c}\text { Groups of } \\
\text { production } \\
\text { according to } \\
\text { OKVED }\end{array}$} & \multicolumn{2}{|c|}{$\begin{array}{c}\text { EP(ths. MW-h } \\
\text { per capita). }\end{array}$} & \multicolumn{2}{c|}{$\begin{array}{c}\text { HE (Gcal per } \\
\text { capita). }\end{array}$} & \multicolumn{2}{c|}{$\begin{array}{c}\text { F (TOE per } \\
\text { capita). }\end{array}$} \\
\cline { 2 - 7 } & 2008 & 2014 & 2008 & 2014 & 2008 & 2014 \\
\hline CA-CB & 56 & 94 & 11 & 13 & 15 & 23 \\
\hline DA-DN & 36 & 33 & 8 & 10 & 28 & 35 \\
\hline E & 9 & 6 & - & - & 315 & 284 \\
\hline
\end{tabular}

The growth of this indicator is one of the conditions to increase workforce productivity (Table8).

TABLE VIII. GROWTH RATE OF POWER AVAILABILITY PER WORKER IN THE SPHERE OF INDUSTRIAL PRODUCTION IN SVERDLOVSK REGION IN 2014 IN COMPARISON WITH $2008(\%)$

\begin{tabular}{|l|c|c|c|}
\hline Groups of production according to OKVED & $\boldsymbol{E P}$ & $\boldsymbol{H F}$ & $\boldsymbol{F}$ \\
\hline CA-CB & 168.0 & 124.7 & 154.6 \\
\hline DA-DN & 92.6 & 123.5 & 123.1 \\
\hline E & 75.4 & - & 90.1 \\
\hline
\end{tabular}

Table 8 outlines that the power availability per worker was reduced in the groups $\mathrm{D}$ and $\mathrm{E}$. Furthermore, the group $\mathrm{E}$ shows a decrease in the fuel consumption per worker.

The energy intensity slowdown demonstrates the efficiency of the energy-saving policies. The Federal Law of November 29, 2007, No. 282-FZ imposes restriction that does not allow publishing indicators in physical units, including the production indicators of industrial products. Thus, the indicator of energy intensity of the production sector in Sverdlovsk region per one enterprise is considered. This indicator is calculated as the ratio of actually consumed energy to the number of enterprises in each group (Table 9).

TABLE IX. ENERGY INTENSITY OF INDUSTRIAL PRODUCTION IN SVERDLOVSK REGION

\begin{tabular}{|c|c|c|c|c|c|c|}
\hline \multirow{2}{*}{$\begin{array}{c}\text { Groups of } \\
\text { production } \\
\text { according to } \\
\text { OKVED }\end{array}$} & \multicolumn{2}{|c|}{$\begin{array}{l}E P(\text { ths. } M W- \\
\text { h per capita) }\end{array}$} & \multicolumn{2}{|c|}{$\begin{array}{c}H E \text { (mln. } \\
\text { Gcal) }\end{array}$} & \multicolumn{2}{|c|}{$F($ ths. TOE) } \\
\hline & 2008 & 2014 & 2008 & 2014 & 2008 & 2014 \\
\hline $\mathrm{CA}-\mathrm{CB}$ & 44 & 99 & 8 & 14 & 12 & 24 \\
\hline DA-DN & 25 & 24 & 6 & 7 & 19 & 25 \\
\hline $\mathrm{E}$ & 5 & 2 & - & - & 173 & 108 \\
\hline
\end{tabular}

Energy consumption was reduced only in group E, while in group $\mathrm{D}$, the decline occurred only in the sphere of electrical power consumption (Table 10).

TABLE X. GROWTH RATE OF ENERGY INTENSITY IN THE SPHERE OF INDUSTRIAL PRODUCTION IN SVERDLOVSK REGION IN 2014 IN COMPARISON WITH $2008(\%)$

\begin{tabular}{|l|c|c|c|}
\hline $\begin{array}{l}\text { Groups of } \\
\text { production } \\
\text { according to } \\
\text { OKVED }\end{array}$ & $\boldsymbol{E P}$ & $\boldsymbol{H F}$ & $\boldsymbol{F}$ \\
\hline CA-CB & 224.9 & 166.9 & 206.9 \\
\hline DA-DN & 96.1 & 128.3 & 127.9 \\
\hline E & 52.1 & - & 62.2 \\
\hline
\end{tabular}

To sum up, there are the following trends in the sector of industry in Sverdlovsk region.

- Increase of the volume of production and revenue. The revenue indicator changes in direct proportion to the production volume indicator in groups $\mathrm{C}$ and D. This change is accompanied by a significant excess of the revenue growth rate over the production growth rate in group E.

- The cost structure of all groups is shifted towards an increase of the category of other expenditures. This category of expenditures prevails in groups $\mathrm{C}$ and $\mathrm{E}$. The share of expenditures for raw and other materials, and salary decreases in all groups.

- All types of expenditures grow, excluding the expenditures for raw and other materials in group $\mathrm{C}$. The expenditures for energy show the greatest increase in the group $\mathrm{E}$.

- An increase of the expenditures for fuel and energy in all groups is accompanied by a reduction of the actual consumption of fuel and energy in groups D and E, and reduction of the consumption of heat energy in group C. 
- The power availability per worker was reduced in groups D and E. The group E shows a decrease in the fuel consumption per worker.

- The energy consumption was reduced in the group E, although it is noted only in the sector of electrical power in group D.

Such trends are largely explained by the monopolization of the industrial sector, that was historically formed under the complete state property and still exists in other forms of ownership. The lack of competitive small and medium enterprises of all kinds of production sectors explains the lack of activity on collecting similar indicators for such forms of enterprises. The current statistical reports for small manufacturing enterprises do not allow collecting indicators comparable to those considered above.

The study of small business in the transportation sector is highly representative in the areas of public transport and freight traffic, as these activities are a clear illustration of how a real entrepreneurial activity can be affordable and demanded.

The transportation sector remains one of the key aspects to ensure the convenient and safe life in the region. In general, this agrees with the primary objectives set by the state regulatory authority for this type of economic activity. Moreover, the conditions to achieve these goals are obvious, easy and accessible: receipt of tax payments, provision of comfortable mobility for citizens, self-employment, as well as establishment of new small service enterprises, related to this type of activity. This example of entrepreneurial activity shows the true purpose of entrepreneurship; that is to provide the necessary balance of personal and public benefits.

The number of vehicles grows in all categories in Sverdlovsk region, except for the bus fleet (Table 11).

TABLE XI. GROWTH OF VEHICLES IN SVERDLOVSK REGION IN 2014 IN COMPARISON WITH 2008 (\%)

\begin{tabular}{|l|c|}
\hline \multicolumn{1}{|c|}{ Type of vehicle } & Growth (\%) \\
\hline Buses & 90.2 \\
\hline Trucks & 131.9 \\
\hline Passenger cars & 133.7 \\
\hline Availability of vehicles (total) & 141.6 \\
\hline
\end{tabular}

Table 12 outlines a lower rate of reduction in passenger turnover and a significant decrease in freight turnover of trucks in the group of small enterprises.

TABLE XII. CHANGE IN PERFORMANCE INDICATORS OF THE TRANSPORTATION SECTOR IN SVERDLOVSK REGION IN 2014 IN COMPARISON WITH 2008 (\%)

\begin{tabular}{|c|c|c|}
\hline Indicator & $\begin{array}{c}\text { Organizations } \\
\text { other than } \\
\text { small business } \\
\text { entities }\end{array}$ & $\begin{array}{c}\text { Small business } \\
\text { entities }\end{array}$ \\
\hline $\begin{array}{c}\text { Incomes of public transport buses } \\
\text { (including shuttle vans) }\end{array}$ & 126.8 & - \\
\hline $\begin{array}{c}\text { Expenditures of public transport } \\
\text { buses (including shuttle vans) }\end{array}$ & 99.8 & - \\
\hline $\begin{array}{c}\text { Passenger traffic of public } \\
\text { transport buses (including shuttle }\end{array}$ & 39.0 & 93.2 \\
\hline
\end{tabular}

\begin{tabular}{|c|c|c|}
\hline Indicator & $\begin{array}{c}\text { Organizations } \\
\text { other than } \\
\text { small business } \\
\text { entities }\end{array}$ & $\begin{array}{c}\text { Small business } \\
\text { entities }\end{array}$ \\
\hline vans) & & \\
\hline Incomes of trucks & 247.8 & - \\
\hline Expenditures of trucks & 245.8 & - \\
\hline Freight turnover of trucks & 387.9 & 49.0 \\
\hline
\end{tabular}

Small enterprises in the sector of public transport offer higher incomes and passenger turnover and lower expenditures in comparison with other organizations.

Statistical control of safety indicators of the transportation sector in the field of passenger and freight traffic is carried out by the State Road Safety Inspectorate. Table 13 shows an increase in the number of road accidents in the category of public transport delivering bus services. That is the category in which the entrepreneurial activities are performed. This fact confirms that the public benefit has to be the goal of entrepreneurial activity; and its substitution with profit making is a threat to life, in the long run it is destructive for the economy and predetermines the additional costs for remediation from antisocial results.

TABLE XIII. TABLE STYLES ROAD ACCIDENTS THAT INVOLVE PUBLIC TRANSPORT AND GROUND-BASED ELECTRIC TRANSPORT (JANUARY-OCTOBER, 2015) [18]

\begin{tabular}{|c|c|c|}
\hline Indicator & $\begin{array}{l}\text { Road } \\
\text { accidents }\end{array}$ & $\begin{array}{c}+/-\% \\
\text { to the same period } \\
\text { of the previous } \\
\text { year }\end{array}$ \\
\hline $\begin{array}{l}\text { Road accidents that involve public } \\
\text { transport delivering bus services } \\
\text { including: }\end{array}$ & 189 & 8.6 \\
\hline $\begin{array}{l}\text { regular city traffic including } \\
\text { passenger drop-off at the specified } \\
\text { public transport stops }\end{array}$ & 111 & 8.8 \\
\hline $\begin{array}{l}\text { regular city traffic including } \\
\text { passenger drop-off at any point not } \\
\text { prohibited by the traffic regulations }\end{array}$ & 5 & 25.0 \\
\hline city traffic on demand & - & - \\
\hline regular suburban traffic & 10 & 150.0 \\
\hline suburban traffic on demand & - & - \\
\hline $\begin{array}{l}\text { regular intercity } \\
\text { (international) traffic }\end{array}$ & 21 & -40.0 \\
\hline intercity (international) traffic & - & - \\
\hline $\begin{array}{c}\text { Road accidents that involve } \\
\text { trolleybuses }\end{array}$ & 11 & -31.3 \\
\hline Road accidents that involve trams & 18 & -30.8 \\
\hline
\end{tabular}

Table 14 also confirms an increasing trend in the number of road accidents in Ural district that affects the transport groups within which an entrepreneurial activity is possible.

TABLE XIV. ROAD ACCIDENTS CAUSED BY A TRAFFIC OFFENCE, URAL DISTRICT, 2014 [18]

\begin{tabular}{|l|c|c|}
\hline \multicolumn{1}{|c|}{ Indicator } & $\begin{array}{c}\text { Road } \\
\text { accidents }\end{array}$ & $\begin{array}{c}+/- \text { \% to the same } \\
\text { period of the } \\
\text { previous year }\end{array}$ \\
\hline committedbytruckdrivers & 1072 & 6.9 \\
\hline committedbybusdrivers & 482 & 10.6 \\
\hline
\end{tabular}




\begin{tabular}{|l|c|c|}
\hline $\begin{array}{l}\text { committed by bus drivers who } \\
\text { have licence for passenger } \\
\text { transportation }\end{array}$ & 324 & 20 \\
\hline committedbytramdrivers & 11 & -15.4 \\
\hline committedbytrolleybusdrivers & 7 & 0 \\
\hline
\end{tabular}

The small business is hardly possible in the types of economic activities that are represented in the Communication section of the Russian Classification of Economic Activities. But it is obvious that there is still a requirement for an objective and comprehensive assessment of this sector within the subject of this study, as it can (and should) become a basic one for the related small enterprises. Thus, Table 15 shows how efficient the activities are in the sector of telecommunications.

TABLE XV. ACTIVITIES IN THE SECTOR OF TELECOMMUNICATIONS, SVERDLOVSK REGION (MLN. RUBLES)

\begin{tabular}{|c|c|c|c|}
\hline Indicator & $\mathbf{2 0 0 8}$ & $\mathbf{2 0 1 4}$ & \% 2014 to 2008 \\
\hline Revenue & 64879.5 & 48380.9 & 74.6 \\
\hline Cost & 50149.7 & 38046.5 & 75.9 \\
\hline $\begin{array}{c}\text { Sales, general and } \\
\text { administrative costs }\end{array}$ & 4850.3 & 3892.3 & 80.2 \\
\hline Technological innovation costs & 5408.9 & 576.1 & 10.7 \\
\hline
\end{tabular}

There is an obvious decline in all indicators, and the most significant decrease is presented by the technological innovation costs.

It would be hard to overestimate the social and economic importance of the agricultural sector. Indeed, there should be a place for small business in this sector. Russian climatogeographic features lead to a variety of assessments of the agricultural sector depending on the region and agricultural crop; but a combination of these data will allow considering the situation fully: how this sector is developing and to what extent the small business segment is taking part in it.

TABLE XVI. CHANGE IN CROP AREA IN SVERDLOVSK REGION IN 2014 IN COMPARISON WITH $2008(\%)$

\begin{tabular}{|c|c|}
\hline Indicator & \% 2014 to 2008 \\
\hline Farms of all categories & 96.0 \\
\hline Farming companies & 91.5 \\
\hline Farms of citizens & 94.5 \\
\hline Private farms and individual entrepreneurs & 123.0 \\
\hline
\end{tabular}

In 2014, the volume of agricultural production of private farms (PF) and individual entrepreneurs performing agricultural activities (IE) was equal to $3803.2 \mathrm{mln}$. rubles in actual prices, including crop production with $2774.3 \mathrm{mln}$. rubles, and livestock production with $1028.9 \mathrm{mln}$. rubles. The agricultural production of PF and IE in value terms increased 2 times for the period from 2010 to 2014, despite the decreasing trend in the number of PF and IE.In 2014, PF and IE of Sverdlovsk region produced $23.7 \%$ of the total volume of agricultural products delivered by PF and IE of the Ural Federal District [22].
TABLE XVII. THE SHARE OF PF AND IE IN THE AGRICULTURAL PRODUCTION IN 2014

\begin{tabular}{|c|c|c|c|}
\hline \multirow[b]{2}{*}{ Region } & \multirow{2}{*}{$\begin{array}{c}\text { Agriculture } \\
\text { (total) }\end{array}$} & \multicolumn{2}{|c|}{ including: } \\
\hline & & $\begin{array}{c}\text { crop } \\
\text { production }\end{array}$ & $\begin{array}{c}\text { livestock } \\
\text { production }\end{array}$ \\
\hline $\begin{array}{l}\text { Ural Federal } \\
\text { District }\end{array}$ & 6.3 & 10.9 & 3.0 \\
\hline Kurgan region & 10.0 & 20.2 & 1.8 \\
\hline $\begin{array}{c}\text { Sverdlovsk } \\
\text { region }\end{array}$ & 5.8 & 10.8 & 2.5 \\
\hline Tyumen region & 6.9 & 7.7 & 6.2 \\
\hline $\begin{array}{l}\text { Chelyabinsk } \\
\text { region }\end{array}$ & 4.8 & 9.9 & 1.7 \\
\hline
\end{tabular}

Assessment of the contribution of small and medium enterprises in the agricultural sector is complicated by the different forms of statistical reports (depending on the size and organizational form of enterprise) that are not comparable in some indicators. The agricultural sector is unique, thus the assessment of agricultural small and medium enterprises requires a special comprehensive analysis that is outside the scope of this study.

As a result, the entrepreneurial potential through the development level of the small and medium enterprises in the real sector of economy was considered. On the basis of proposed methodology its complex description was obtained. This process was demonstrated in case of Sverdlovsk region. The proposed grouping of indicators showed the efficiency and consumption nature of the analyzed sectors, and regional trends of opportunities to guarantee the social and economic development of the region.

\section{CONCLUSION}

The performed analysis allows demonstrating that the development system of SME and entrepreneurial potential is hardly focused on the real sector of economy. The application of this methodology highlights that the development of entrepreneurship needs more than just declarations. It requires precise, highly professional and efficient administrative work, which should combine the analysis of commercial side of the economic activities with assessment of its social importance. Moreover, one should create the real conditions and supporting measures for the small enterprises to be established and operate in the most significant areas of the real sector of economy. Productive Entrepreneurial Activity is an assessment criterion of how the business environment considers a quality of regional management as an effective coordination of the interests of the parties concerned, and as a mechanism for launching the self-organization processes [19]. As the result, a series of recommendations can be formulated:

- To improve the development programs of small and medium enterprises, in accordance with the features of socio-economic systems of the regions, bringing a focus on the existing economic sectors that were formed under the influence of climatic and geographical factors and therefore determine the competitive advantages of the territories.

- To define and to document the types of economic activities that are priority for the development of small 
and medium innovative manufacturing enterprises, with a view to implement the government support measures.

- To organize regular field studies of small and medium enterprises by the method of continuous reading, for the purpose of defining the factors that hinder development of specific activities.

- To specify additional indicators of business performance in the context of the main sections of OKVED (absolute and relative contribution of small enterprises to the gross regional product, absolute and relative contribution to the regional tax payments and non-budgetary funds, a sectoral structure of employees of small enterprises, a sectoral structure of payroll fund).

- To provide security and protection against corruption and crime to the innovative-active manufacturing enterprises by means of establishment of a system of state insurance of such enterprises.

\section{Acknowledgment}

The article was prepared in accordance with the research plan of the Institute of Economics of the Ural branch of the Russian Academy of Sciences "Methodology of Research of the Structural Changes in the Industry Markets in the Context of the Transforming Mechanisms of State Resource Management" No. 0404-2015-0015 with the Information System of State Tasks and Research Plans of the Federal Agency for Scientific Organizations.

[1] Z.J.Acs, C.Armington,"Employment growth and entrepreneurial activities in cities", Regional Studies, vol. 38, pp. 911-927, 2004.

[2] S.Beugelsdijk, "Entrepreneurial Culture, Regional Innovativeness and Economic Growth", Regions and Fiscal Federalism, pp.1-17 [44th Congress of the European Regional Science Association: ", Porto, Portugal, 25th $\quad$ 29th August 2004] https://www.econstor.eu/handle/10419/117054

[3] Federal Portal of the Small and Medium Business. Ministry of Economic Development of the Russian Federation, http://smb.gov.ru/

[4] "Financial Condition and Expectations of the Small and Medium Business in 2015", Russian Bank for Small and Medium Enterprises Support, Joint-Stock Company (SME Bank, JSC). Moscow: Analytical Center, 2015, http://nisse.ru/analytics/research/

[5] E.L.Glaeser, W.R.Kerr, "Local industrial conditions and entrepreneurship: How much of the spatial distribution can we explain?", Journal of Economics \& Management Strategy, vol. 18, pp. 623-663, 2009

[6] E. J. Malecki, "Geographical environments for entrepreneurship", International Journal of Entrepreneurship and Small Business,vol. 7, pp.175-190, 2009.

[7] A. Mirzaei, R.S.F. Al-Khouri, "The resilience of oil-rich economies to the global financial crisis: Evidence from Kuwaiti financial and real sectors", Economic Systems, Elsevier, vol. 40(1), pp.93-108, 2016.

[8] V. Radaev, "The development of small entrepreneurship in Russia, WIDER Discussion Papers", World Institute for Development Economics (UNU-WIDER), vol. 2001/135, http://hdl.handle.net/10419/52995

[9] "REDI: The Regional Entrepreneurship and Development Index", Measuring regional entrepreneurship Final report,http://ec.europa.eu/regional_policy/sources/docgener/studies/pdf/r egional entrepreneurship development index.pdf
[10] "Small and Medium Entrepreneurship in Russia", European Investment Bank Luxembourg, November 2013 http://www.eib.org/attachments/efs/econ_study_small_and_medium_ent repreneurship_in_russia_en.pdf

[11] B.Spigel, "Bourdieu, culture, and the economic geography of practice: entrepreneurial mentorship in Ottawa and Waterloo, Canada", Journal of Economic Geography, pp. 1-24, 2016. https://www.researchgate.net/publication/305396795_Bourdieu_culture_ and_the_economic_geography_of_practice_entrepreneurial_mentorship in Ottawa and Waterloo_Canada

[12] "State program of Chelyabinsk region On the Complex Support and Development of the Small and Medium Business in Chelyabinsk Region in 2015-2017",http://www.chelbiznes.ru/programsuppor/r?article=1451

[13] "State program of Khanty-Mansy Autonomous Region - Yugra On the Social and Economic Development, Investments and Innovations of Khanty-Mansy Autonomous Region - Ugra in 2014-2020", http://www.admkogalym.ru/

[14] "State program of Kurgan region On the Development and Support of the Small and Medium Business in Kurgan Region in 2014-2020", http://www.economic.kurganobl.ru/assets/files/predprinimat/zakon/ppko _20131014_505_red_20150604.pdf

[15] "State program of Sverdlovsk region On the Increase of the Investment Attractiveness of Sverdlovsk Region until 2020", http://economy.midural.ru/

[16] "State program of Tyumen region On the Main Development Directions of the Small and Medium Business until 2020", http://www.tyumenregion.ru/support/enterprises/gosprogramm/

[17] "State program of Yamalo-Nenets Autonomous Region On the Economic Development and Innovative Economy in 2014-2020", http://de.gov.yanao.ru/doc/mp/normativka/region/1111p_25122013.pdf

[18] "Sverdlovsk Region: Data on the Road Safety Indicators", Official website of the State Traffic Inspectorate, http://www.gibdd.ru/r/66/stat/

[19] A.I.Tatarkin, N.B. Akatov, D.V. Sazonov,"Regional Requirements as the Basis for Entrepreneurial Activity Management", Journal of Economic Theory, vol.1, 2011, pp. 48-54.

[20] E. Yu.Tereshchenko, Yu.K. Beseda,"Theoretical Aspects of the Way to Define the Concept and Structure of the Real Sector of Economy", Science and Economics: e-magazine, vol. 2, 2011, http://archive.nbuv.gov.ua/portal/soc_gum/nie/2011_2/175-185.pdf

[21] "The Quality Index of the Conditions for the Small and Medium Businessin 2013-2014: Imbalances in the Regions", Russian Bank for Small and Medium Enterprises Support, Joint-StockCompany (SMEBank, JSC). Moscow: AnalyticalCenter, 2015 , http://nisse.ru/analytics/research/

[22] "The Role of Private Farms and Individual Entrepreneurs in the Agricultural Sector in Sverdlovsk Region", Territorial Department of the Federal State Statistics Service, http://sverdl.gks.ru/

[23] "Unified Interdepartmental Information and Statistical System", http://www.fedstat.ru/indicators/start.do

[24] E.O.Wegner-Kozlova, E.S.Mezentseva, Methodological Aspects of Assessing Entrepreneurial Potential in the Regions, Monograph, Yekaterinburg: Institute of Economics of the Ural branch of the Russian Academy of Sciences: AMB Publishing Company, 2014, p. 96, https://elibrary.ru/item.asp?id=26582352 